\title{
THE EFFECT OF SELENIUM SUPPLEMENTATION ON LUNG FUNCTIONS IN PATIENTS WITH IDIOPATHIC PULMONARY FIBROSIS
}

\author{
BY \\ Lamia El Wakeel ${ }^{\text {a }}$ Ahmed Mahmoud Abdelhafeez ${ }^{\mathrm{b}}$, Nada Hazem ${ }^{\mathrm{c}}$, Mona Schaalan ${ }^{\mathrm{d}}$ \\ FROM
}

a Associate Professor of Clinical Pharmacy, Clinical Pharmacy Department, Ain Shams University, Egypt.

b Associate Professor of Chest Disease, Faculty of Medicine, Cairo University, Embaba, Egypt

c Teaching Assistant, Clinical Pharmacy and Pharmacy Practice Department, Misr International University, Egypt.

d Associate Professor and Head, Clinical Pharmacy and Pharmacy Practice Department, Misr International University, Egypt.

\begin{abstract}
Idiopathic pulmonary fibrosis (IPF) is a common aggressive form of the idiopathic interstitial pneumonias of unknown cause. It is chronic, progressive, irreversible, fibrosing and lethal lung disease with a poor prognosis. The cardinal symptom of IPF is dyspnea; however, other pulmonary and extra-pulmonary symptoms are often present. The study aims to implement a novel pharmaceutical approach by administration of selenium accompanied with prednisone in an attempt to improve clinical outcome of IPF patients to decrease other medications toxicities and improve patients' quality of life. This study was conducted at Kasr El-Ainy Chest Hospitals, from April 2012 to March 2014.The work included forty clinically and radiologically diagnosed cases of IPF and twenty healthy controls, they were subdivided into Group I: twenty IPF patients received; N-acetyl cysteine (NAC) $600 \mathrm{mg} / 3$ times (for 3 months).Group II: twenty IPF patients received: Selenium $200 \mathrm{mcg} / \mathrm{day}$ (for 3 months). All cases subjected to medical history, clinical examination, plain X-ray chest, and High resolution computed tomography (HRCT), 6-minute walk test, and spirometry. All patients signed informed consents. The comparison of Selenium group with NAC revealed a significant increase in both of forced vital capacity (FVC) and Forced expiratory volume in the first second (FEV1) $(\mathrm{p}=0.008,0.016$, respectively), using a Mann-Whitney test. There was no remarkable adverse drug reactions observed in both groups, and no serious drug interactions. This study showed that selenium supplementation in IPF patients' significantly improved pulmonary functions, which reflect an antioxidant capacity. In addition patients' clinical presentation shown as significant decrease of coughing and dyspnea on exertion.
\end{abstract}

Key Words: Idiopathic Pulmonary fibrosis; Selenium; Spirometry 


\section{Introduction}

Idiopathic pulmonary fibrosis (IPF), the common aggressive form of the idiopathic interstitial pneumonias of unknown cause. It is chronic, progressive, irreversible, fibrosing and lethal lung disease with a poor prognosis (Raghu et al. 2011). The histological hallmark of IPF pattern is patchy interstitial fibrosis.(Bois 2012) The fibrosis is temporary heterogeneous with architectural destruction, dense scarring with honey combing and scattered fibroblast foci(Raghu et al. 2011). IPF is an age related lung disease that occurs in middle aged elderly adults (median age at diagnosis is 66 years, range 55-75 years), and is limited to the lungs. The annual incidence of IPF is rising and estimated to be between 4.6 and 16.3 per 100,000 people and the prevalence is 13 to 20 cases per 100, 000. (Pardo and Selman 2012)There is a higher predominance of the disease in men $(1.5$ to $1.7 ; 1)$ than in women and frequency increases with age. It has a poor prognosis with a 5 year mortality rate between 50 and $70 \%$ (Loomis-King, Flaherty, and Moore 2013). The most important environmental risk factors are cigarette smoking and exposure to metal and wood dust. Genetic transmission occurs in about $0.5-3.7 \%$ of patients with IPF.(Taskar and Coultas 2006) The influence of several comorbid conditions: obesity, diabetes mellitus, gastroesophageal reflux, pulmonary hypertension, obstructive sleep apnea, Coronary artery disease (CAD). and emphysema - on clinical course of IPF remains to be fully defined (Loomis-King et al. 2013). Although IPF occurs in older patients with comorbid diseases, most patients with IPF die as a direct consequences of their lung fibrosis (Kliment and Oury 2010). From the time of IPF diagnosis, there is a mean survival of 3-5 years. A diagnosis of IPF is made from a thorough history and physical examination, chest radiography, pulmonary function test; high resolution computed tomography (HRCT) and a lung biopsy. (Sverzellati 2013) Patients typically present with a history of greater than 3 months of dyspnea and non-productive cough. (Kliment and Oury 2010).Up to date, there is no worldwide proven pharmacological therapy for IPF. The routine pharmacotherapeutic options include: Corticosteroids, Cytotoxic and Antioxidants. (Raghu et al. 2015).Agents that failed to show efficacy: Prednisone (antiinflammatory) and Azathioprine (immunosuppressive agent), Interferon g-1b (antifibrotic, antiproliferative),Etanercept ( TNF-a), Warfarin, Colchicine ,Calcium channel blockers, Atorvastatins and Cyclophosamides(Raghu et al. 2015). PANTHERIPF trial (2009-sep. 2014) also stressed on that currently used triple-drug therapy consisting of prednisone, is a potentially harmful combination to people with IPF that the arm with this combination was stopped for safety concerns.(Loomis-King et al. 2013). The study aims to implement a novel pharmaceutical approach by administration of Selenium in an attempt to improve clinical outcome of IPF patients, decrease other medications toxicities and improve patients' quality of life.

\section{Subjects \& Methods}

The work included forty clinically and radiologically known cases of IPF. They were further sub-divided into two groups: Group I: Twenty IPF patients received; Nacetyl cysteine $600 \mathrm{mg}$ orally three times daily (Antoniou et al. 2007). Group II: twenty IPF patients received: Selenium $200 \mathrm{mcg} / \mathrm{day}$ orally.The participants were adult patients $>20$ years old with clinical history and radiological findings on HRCT compatible with the diagnosis of IPF. Exacerbation of IPF, patients with superimposed 
chest infection (pneumonic infiltrate diagnosed by CT) and other system affection e.g., Cardiac and musculoskeletal system were excluded. Protocol has been approved by ethical committee of faculty of Pharmacy Ain Shams University, Approval number (24). Prospective, randomized (patients attending hospital on Saturday were assigned to control group, while patients attending on Monday were assigned to test group), controlled, study.

\section{Settings:}

Study was conducted at chest department, Kasr Ainy hospitals, from April 2012 to March 2014

\section{Patients and Methods}

All patients were subjected to the following; Full history taken and Clinical examination, stressing upon: age, sex, occupational, environmental, smoking and drug history, Plain X-ray of the chest, HRCT chest using general electric (GE) multislice four detector scanner, Arterial blood gas analysis using a blood gas analyzer (PHOX PLUS C). Pulmonary function tests: Flow/volume loop using body plethysmography with highly transparent box; Sensor-medics V max series, 2130 Spirometer, V6200 Autobox, 6200DL. Spirometry measurements are evaluated by comparison of the results with appropriate reference value based on age, height, sex, and race. The Forced vital capacity (FVC), the forced expiratory volume in the first second (FEV1), the ratio of FEV1 to FVC measured. The presence of an FVC/FEV1 $>0.70$ Together with FVC $<80 \%$ predicated confirm the presence of restrictive lung disease.Six-minute walk test: Conducted in $30 \mathrm{~m}$ long, flat corridor, and transit-free to avoid turn more often which slows patient's pace. Standardized instructions and encouragement were given, according to ATS guidelines. The walk testing was discontinued if the patient had thoracic pain, intolerable dyspnea, cramps, dizziness, staggering, diaphoresis, pallor, or an $\mathrm{SpO} 2<90 \%$.

\section{Statistical analysis}

Statistical presentation and analysis of the results of the present study was conducted, using the mean, standard deviation, kruskal-kallis test and Mann-Whitney test. According to the computer program SPSS Version 21, p value less than 0.05 was considered statistically significant.

\section{Results}

Regarding demographic characteristics; No significant difference between both groups was found in patient demographics. Table 1. There was no statistical difference in patient's parameters at baseline but there was a statistically significant difference in spirometry results at the end of the study as shown in Table 2 . In addition to a statistically significant difference in Six minutes' walk test between test group and control group at the end of the study as shown in table 3 . 
The present study demonstrated that the mean \pm SD age among the IPF patients was $51.5 \pm 8.5$ (range 24-75 years) with no statistically significant difference.

\begin{tabular}{|c|c|c|c|}
\hline Parameters & $\begin{array}{l}\begin{array}{l}\text { Control } \\
\text { (NAC) } \\
(n=20)\end{array} \\
\end{array}$ & $\begin{array}{l}\text { Test (Se) } \\
(n=20)\end{array}$ & $\begin{array}{l}\text { Significance } \\
\text { P value }\end{array}$ \\
\hline $\begin{array}{l}\text { Age (years); } \\
\text { mean } \pm \text { SD }\end{array}$ & $\begin{array}{ll}51.5 & \pm \\
8.5 & \\
\end{array}$ & $\begin{array}{ll}51.3 & \pm \\
8.7 & \end{array}$ & 0.845 \\
\hline $\begin{array}{l}\text { Sex; n (\%) } \\
\text { Male } \\
\text { Female }\end{array}$ & $\begin{array}{l}11 \\
(55 \%) \\
9 \\
(45 \%)\end{array}$ & $\begin{array}{l}9(45 \%) \\
11 \\
(55 \%)\end{array}$ & 0.766 \\
\hline
\end{tabular}

\section{Table 2: Lung Functions}

\begin{tabular}{l|l|l|l}
\hline Parameter & Time & Control & Test
\end{tabular}

$P$ value (month) 


\begin{tabular}{|l|l|l|l|l|}
\hline & & $\begin{array}{l}\text { (NAC) } \\
(\text { Selenium })\end{array}$ & \\
& & $(\mathrm{n}=20)$ & $(\mathrm{n}=20)$ & \\
\hline \multirow{2}{*}{ FVC \% } & 0 & $\begin{array}{l}36.5 \\
\pm 12.5\end{array}$ & $39.4 \pm 15.8$ & 1.000 \\
& & $\begin{array}{l}32.1 \pm \\
9.4\end{array}$ & $49.5 \pm$ & 0.008 \\
\cline { 2 - 5 } & 3 & $39.0 \pm$ & $40.2 \pm 15.2$ & 1.000 \\
\hline \multirow{2}{*}{ FEV1 \% } & 0 & 12.8 & & \\
\cline { 2 - 5 } & 3 & $33.7 \pm$ & $50.6 \pm$ & 0.016 \\
& & 8.2 & 17.4 & \\
\hline
\end{tabular}

Table 3: Six Minutes' Walk Test

\begin{tabular}{|c|c|c|c|c|}
\hline \multirow[t]{2}{*}{ Parameter } & \multirow{2}{*}{$\begin{array}{l}\text { Time } \\
\text { (month) }\end{array}$} & \multirow{2}{*}{$\begin{array}{l}\text { Control } \\
(n=20) \\
\end{array}$} & \multirow{2}{*}{$\begin{array}{l}\text { Test } \\
(n=20)\end{array}$} & $\mathrm{P}$ values \\
\hline & & & & $\begin{array}{l}\text { Between } \\
\text { groups }\end{array}$ \\
\hline 6MWT & 0 & $\begin{array}{l}191.9 \\
\pm 88.7 \\
\end{array}$ & $\begin{array}{l}167.4 \\
\pm 106.8 \\
\end{array}$ & 1.000 \\
\hline (meters) & 3 & $\begin{array}{l}229.2 \quad \pm \\
93.7\end{array}$ & $\begin{array}{ll}352.7 & \pm \\
110.1 & \\
\end{array}$ & 0.004 \\
\hline
\end{tabular}

* P-Value $<0.05$ statistically significant
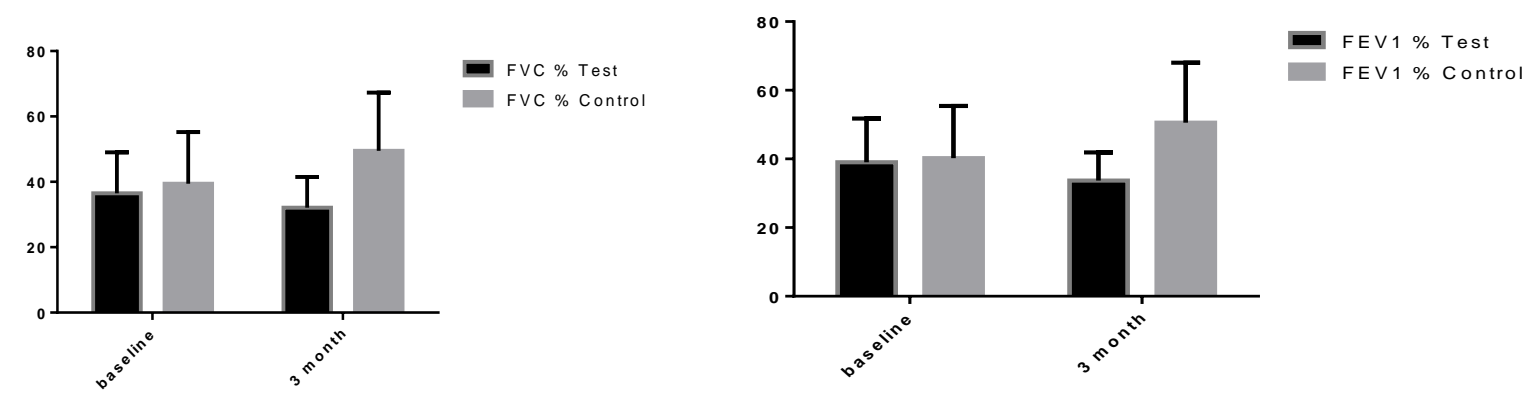

Figure 1: Forced Vital Capacity of test group compared to control group, at baseline and at the end of the study.
Figure 2: Forced expiratory volume in the first second of test group compared to control group, at baseline and at the end of the studv. 


\section{Discussion}

IPF is a uniformly fatal disease with a variable rate of progression. In this study we explored the impact of selenium supplementation on improvement of patients lung functions and walking distance. The present study demonstrated that the mean \pm SD age among the IPF patients was 51.5 \& 8.5 (range 24-75 years) with no statistically significant difference. Similar results were reported by Taghreed et al. as they found that the mean \pm SD age among the IPF patients was $48.30 \pm 12.60$ years. While Lindell et al and Ryerson et al., found that the mean \pm SD age among IPF patients IPF patients were $66.19 \pm 10.93,63.90 \pm 11.60$ years, respectively. (Abu Youssef et al. 2015)The use of acetyl cysteine has been suggested to benefit patients with idiopathic pulmonary fibrosis by favorably altering the oxidative state of the lung (Swigris JJ, Brown KK, Behr J et al). In the IFIGENIA study, a three-drug regimen consisting of azathioprine, prednisone, and acetyl cysteine preserved the FVC better than a two- drug regimen consisting of azathioprine and prednisone (Raghu G, Anstron KJ, King TE et al). This Arm of the study was stopped due to mortality and serious adverse effects. In PANTHER study, it found that over a 60-week period, acetyl cysteine (at a dose of $600 \mathrm{mg}$ three times a day) was not associated with preservation of the FVC, as compared with a matched placebo, in patients with idiopathic pulmonary fibrosis who had mild-to-moderate impairment in pulmonary function.(Martinez, Fernando J, Joae A.de Andrate, Talmadge E.King 2014).The present study demonstrated that there was no significant difference in lung functions in NAC group before and after treatment in agreement with the panther study (Martinez, Fernando J, Joae A.de Andrate, Talmadge E.King 2014).

It is hypothesized that changes in distance walked during a six-minute-walk test (6MWT) would add prognostic information to changes in FVC and FEV1. The present study highlighted that there was no significant difference in the distance walked in NAC group before and after treatment in agreement with panther study (Martinez, Fernando J, Joae A.de Andrate, Talmadge E.King 2014). In addition to a positive correlation between the worsening of lung functions and the decrease in the distance walked.(Flaherty et al. 2006).

No side effects was reported except $40 \%$ of NAC patients experienced GI side effects and also no drug interactions were reported.

To our knowledge now there are no studies discussing the use of Selenium in IPF, but there was a significant improvement in lung functions in Selenium group at end of the study compared to NAC shown as FVC and FEV1 ( $\mathrm{p}=0.008,0.016$, respectively). Conclusively, this study showed that selenium supplementation showed significant improvement in 6MWT indicating an improvement in exercise tolerance and a significant improvement in Spirometry parameters indicating an improvement in lung functions.

\section{References:}


Abu Youssef, Hoda A., Youssriah Y. Sabry, Mohamed N. Sadek, Marwa M. Shaban, and Sameh I. Hafez. (2015): "Study of the Relationship of Dyspnea with Depression and Functional Status in Patients with Interstitial Lung Disease." Egyptian Journal of Chest Diseases and Tuberculosis 64(1):269-75. Retrieved (http://linkinghub.elsevier.com/retrieve/pii/S042276381420015X).

Antoniou, Katerina M., Athanasia Pataka, Demosthenes Bouros, and Nikolaos M. Siafakas. (2007): "Pathogenetic Pathways and Novel Pharmacotherapeutic Targets in Idiopathic Pulmonary Fibrosis."Pulmonary harmacology \& therapeutics 20(5):453-61. Retrieved July 4, 2014 (http://www.ncbi.nlm.nih.gov/pubmed/16516512).

Bois, Roland M. (2012): "An Earlier and More Confident Diagnosis of Idiopathic Pulmonary Fibrosis." European respiratory review 21(124):141-46.

Flaherty, Kevin R. et al. (2006): "Idiopathic Pulmonary Fibrosis: Prognostic Value of Changes in Physiology and Six-Minute-Walk Test."American journal of respiratory and critical care medicine174(7):803-9.Retrieved November12, 2014 (http://www.pubmedcentral.nih.gov/articlerender.fcgi?artid=2648064\&tool=pm centrez\&rendertype=abstract).

Kliment, Corrine R. and Tim D. Oury. (2010): "Oxidative Stress, Extracellular Matrix Targets, and Idiopathic Pulmonary Fibrosis." Free radical biology \& medicine 49(5):707-17. Retrieved June 3, 2014 (http://www.ncbi.nlm.nih.gov/pubmed/20452419).

Loomis-King, Hillary, Kevin R. Flaherty, and Bethany B. Moore. (2013): "Pathogenesis, Current Treatments and Future Directions for Idiopathic Pulmonary Fibrosis." Current opinion in pharmacology 13(3):377-85. Retrieved May 29, 2014 (http://www.ncbi.nlm.nih.gov/pubmed/23602652).

Martinez FJ, de Andrade JA, Anstrom, KJ, King TE and Raghu G (2014): "Randomized Trial of Acetylcysteine in Idiopathic Pulmonary Fibrosis." The New England journal of medicine370:2093-2101. Retrieved (http://www.ncbi.nlm.nih.gov/pubmed/24836309).

Pardo, Annie and Moisés Selman. (2012): "Role of Matrix Metaloproteases in Idiopathic Pulmonary Fibrosis." Fibrogenesis \& Tissue Repair 5(Suppl 1):S9. Retrieved (http://www.fibrogenesis.com/content/5/S1/S9).

Raghu G, Anstron KJ, King TE et al. prednisone, azathioprine and Nacetylcysteine for pulmonary fibrosis. N Engl J Med (2012):,366: 1968-1977

Raghu, Ganesh et al. (2011): “An Official ATS/ERS/JRS/ALAT Statement: Idiopathic Pulmonary Fibrosis: Evidence-Based Guidelines for Diagnosis and Management." American journal of respiratory and critical care medicine 183(6):788-824. Retrieved May 2014 (http://www.ncbi.nlm.nih.gov/pubmed/21471066). 
Raghu, Ganesh et al. (2015): "AMERICAN THORACIC SOCIETY An Of Fi Cial ATS / ERS / JRS / ALAT Clinical Practice Guideline : Treatment of Idiopathic Pulmonary Fibrosis An Update of the 2011 Clinical Practice Guideline." 192:319.

S.F Taghreed, R.H. Manal, E. Taghreed, I.A. Omaima (2012): Anxiety and depression among patients with bronchial asthma, chronic obstructive pulmonary disease and diffuse parenchymatous lung diseases, Egypt. J. Hosp. Med. 49 718-731

Swigris JJ, Brown KK, Behr J (2010): et al. The SF.36 and SGRQ: Validity and first look at minimum important difference in IPF. Respir Med; 104:296-304.

Sverzellati, N. (2013): "Highlights of HRCT Imaging in IPF." Respiratory Research 14(Suppl 1):S3. Retrieved (http://respiratory-research.com/content/14/S1/S3).

Taskar, Varsha S. and David B. Coultas. (2006): "Is Idiopathic Pulmonary Fibrosis an Environmental Disease?" Proceedings of the American Thoracic Society 3(4):293-98. Retrieved June 9, 2014 (http://www.ncbi.nlm.nih.gov/pubmed/16738192). 


\section{الملخص العربي \\ تأثير أعطاء السيلينيوم على وظائف الرئة لمرضى التليف الرئوي مجهول السبب

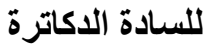

(') لمياء محمد الوكيل ، (") أحمد محمود عبدالحفيظ ، (") ندى حازم عبدالرحيم ، (4) منى فرج شعلان

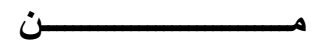

(1) أستاذ مساعد الصيدلة الأكلينيكية كلية الصيدلة ـ جامعة عين شمس ، (؟) أستاذ مساعد أمر اض الصدر كلية

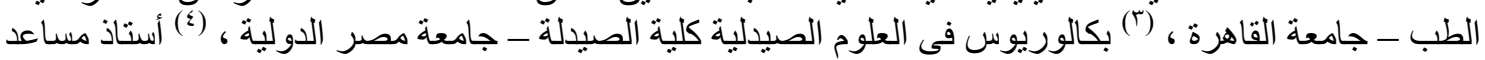
الكيمياء الحيوية والقائم باعمال رئيس قسم الصيدلة الأكلينيكية كلية الصيدلة ـ جامعة مصر الدية الدولية

التليف الرئوي مجهول السبب (IPF)، هو النوع المنتشر من الالتهاب الرئوى الخلالي مجهول السبب و هو مرض مزمن تصأعدى، غير معكوس و عادة من امر اض الرئة الرئة القاتلة.

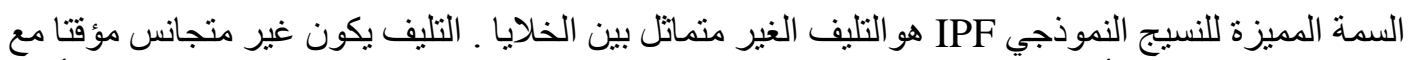

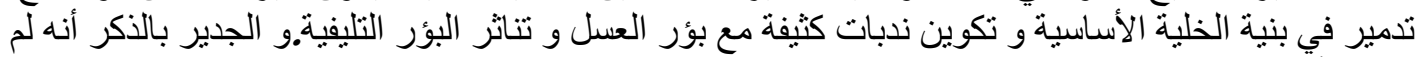



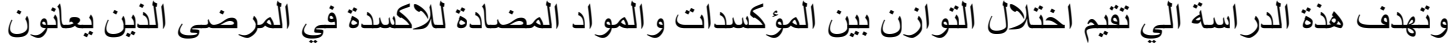

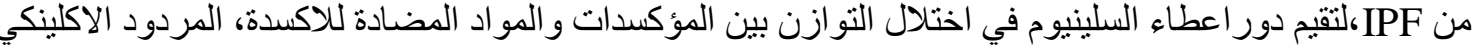

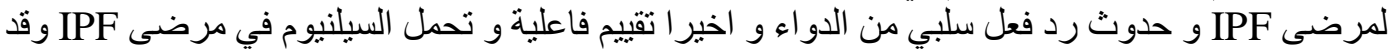

تضمنت الدر اسة 40 مريض تم تقسيمه عشو ائيا إلى مجمو عتين : المجمو عة الأولى : تتألف من عشرين مريضا



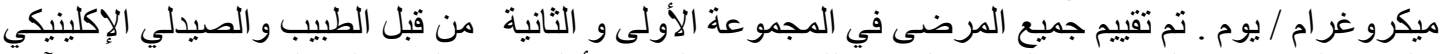

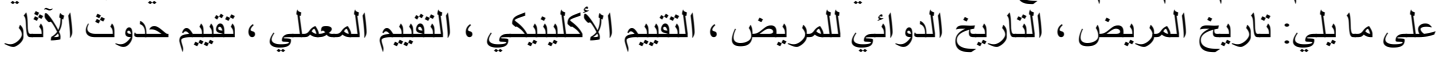
الجانبية و اختبار ات وظارئف المريضف الرئة

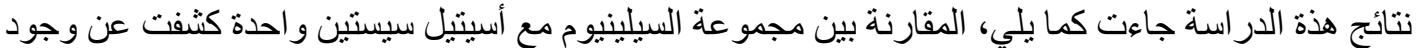

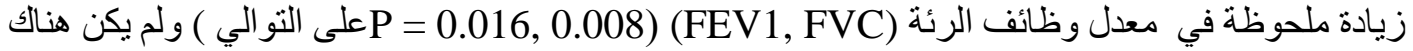
تفاعلات دو ائية ضارة لوحظت في المجمو عتين و تنين استخلاص ان

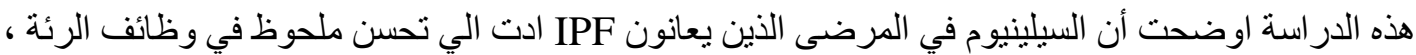

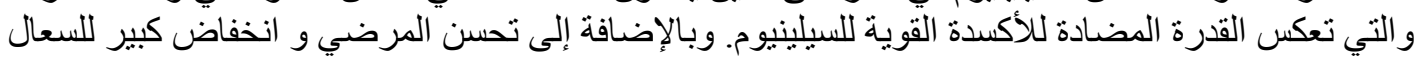
وضيق التنفس عند بذل المجهود. 